\title{
ВПЛИВ КОРМОВОЇ ДОБАВКИ ОРГАНІЧНОГО ПОХОДЖЕННЯ НА СТАТЕВУ АКТИВНІСТЬ БАРАНІВ-ПЛІДНИКІВ
}

\author{
Похил Володимир Іванович \\ кандидат сільськогосподарських наук, доцент \\ Дніпровський державний аграрно-економічний університет \\ ORCID: 0000-0002-2994-879X \\ v_pohil@ukr.net \\ Похил Олена Миколаївна \\ кандидат сільськогосподарських наук, доцент \\ Дніпровський державний аграрно-економічний університет \\ ORCID: 0000-0002-7477-6501 \\ pohil.elena@gmail.com \\ Миколайчук Людмила Петрівна \\ асистент \\ Дніпровський державний аграрно-економічний університет \\ ORCID:0000-0001-5331-719X \\ lyudmila.mikolajchuk@gmail.com

\section{Павленко Роман Анатолійович} \\ магістр \\ Дніпровський державний аграрно-економічний університет
}

Організація збалансованої годівлі, що задовольняє потреби плідників в поживних речовинах і вітамінах, за певного фізіологічного стану і рівня продуктивності - один з головних чинників процесу забезпечення повноцінного сперматогенезу та якісних показників сперми. У зв'язку з тим, що з багатьох причин спостерігається дефріцит білку в кормових раціонах (ціноутворення, якість кормових засобів, конкуренція), то забезпечення достатньої кількості протеїну в ньому є однією з головних умов отримання якісної спермопродукиії. Наведено результати досліджень впливу кормової добавки «Бефіто» органічного походження на відтворювальну здатність і якість спермопродукиії баранів-плідників породи овець придніпровська м'ясна. Встановлено, що використання кормової добавки «Бефріто» в раціонах забезпечує покращення процесу сперматогенезу та впливає на підвищення кількісних і поліпшення якісних показників спермопродукиії. Рівень часу на отримання одного еякуляту у плідників 9,1-10,8 с, що вказує на їх високу статеву активність та потенцію. Об'єм отриманого еякуляту баранів дослідної групи на 11,7 \%, активність сперміїв на 3,7 \%, концентрація сперміїв в еякуляті на 13,9 \% більше в порівнянні з однолітками контрольної. Перевага плідників дослідної групи спостерігається за загальною кількістю сперміїв в еякулятіі становить + 27,3 \%. При цьому не спостерігається тератогенності статевих клітин. Рівень патологічних спермальних форм в еякулятах в межах фізіологічної норми (< 14 \%). Враховуючи середній об'єм еякуляту від баранів-плідників дослідної групи, було отримано15,8 спермодоз в розрахунку на 1 голову проти 14,2 в контролі, що на 11,3 \% більше. Отримані результати дозволяють вважати доиільним застосування кормової добавки «Бефріто» для поліпшення процесу сперматогенезу та якості сперми і рекомендувати як найбільш еффективної.

Ключові слова: барани-плідники, відтворювальна здатність, кормова добавка, амарант, об'єм еякуляту, спермопродукція, реотаксис, концентрація сперми.

DOl: https://doi.org/10.32845/bsnau.lvst.2020.3.10

У сучасних умовах розвитку світового тваринництва, коли біотехнологія і зокрема штучне осіменіння стали основним методом відтворення стад, важливе значення мають плідники як у племінній роботі, так підвищенні продуктивності стад сільськогосподарських тварин [8].

Інтенсифікація відтворення овець обумовлюється цілим комплексом біологічних, зооінженерних, ветеринарних і організаційно-господарських факторів. Серед них $є$ важливі : ефективне використання фундаментальної науки, удосконалення порід овець, спрямоване вирощування ремонтного молодняка, рівень повноцінної годівлі у залежності від фізіологічного стану тварин, умови утримання, скоростиглість тварин, оплата спожитого корму продукцією, тривалість використання репродуктивного поголів'я, плодючість і багатоплідність, рівень племінної справи, кваліфікація зооветеринарних

фахівців. Всі ці фактори потребують подальшого вивчення теорії і передової практики біотехнології відтворення стад в галузі вівчарства з метою підвищення конкурентоздатності вітчизняних порід овець та поліпшення економічної ефективності галузі вцілому [11].

В недалекому минулому селекційна робота у галузі була спрямована на збільшення настригу вовни та покращення ії якості. Для сучасного етапу характерним $€$ те, що центральна ланка в селекції овець перенесена з вовнової продуктивності на м'ясну, так як в даний час економічно значимою продукцією у вівчарстві є м'ясо - баранина, частка якої в валовому доході від реалізації всієї отриманої продукції, становить 85-90 \% і більше. 
Рівень виробництва баранини тісно пов'язаний з показниками відтворення маточного поголів'я, а основним резервом даного збільшення $є$ - підвищення плодючості овець.

Нині набувають особливого значення дослідження, в яких не тільки викладаються методи і кінцеві результати, але і проводиться аналіз дії різних факторів, що можуть вплинути на статеву активність та рівень відтворювальної здатності репродуктивного поголів'я.

Повноцінна та збалансована годівля репродуктивного поголів'я овець, відповідно до їх фрізіологічного стану - основна умова забезпечення нормального відтворення у вівцематок та статевої активності у баранів-плідників.

Із джерел наукової літератури відомо, що кількість і якість сперми баранів значною мірою обумовлена умовами годівлі, утримання, режимами статевого використання, сезонами року та іншими паратиповими факторами зовнішнього середовища [9].

Разом з тим дослідженнями доведено можливість позитивного впливу збалансованої та поліпшеної годівлі на спермопродукцію плідників, де разом з підвищенням поживності раціону збільшується не тільки число сперміїв у еякуляті, але й поліпшуються якісні показники сперми. При цьому встановлено негативний вплив на спермопродукцію баранів-плідників не тільки недокорму, але й перекорму, а також тих випадків, де до складу раціону входять одноманітні корми [5].

Так як білок - це основа життя, то йому належить вирішальна роль у забезпеченні як повноцінного харчування людей, так і належної збалансованої годівлі тварин, де значення його в обмінних процесах організму зумовлено насамперед як достатнє джерело енергії, оскільки 1 г перетравного протеїну кормів еквівалентний 4,35 ккал, або 18,21 кДж (за Титус).

При недостатній кількості протеїну в раціоні, або його неповноцінності за амінокислотним складом, у самок під час підготовки до сезону парування, подовжується період від ягніння до першої овуляції. Порушується процес овогенезу та нормальний розвиток яйцеклітин, при цьому погіршується їхня якість та проходження овуляційних процесів у самок, як результат - зниження запліднюваності, ослаблення або відсутність статевих рефолексів і тічки, аліментарна безплідність. Поряд з цим у кітних вівцематок можлива резорбція запліднених яйцеклітин і навіть плодів, народження слабкого недорозвиненого молодняку, при цьому також має місце негативний баланс азоту [4].

Недостатня кількість протеїну в раціоні овець на рівні $1,0 \%$ додатково витрачається до 2,0 \% кормів із розрахунку їх енергетичної поживності, при цьому має місце перевитрата кормів, що призводить до підвищення собівартості виробництва продукції та зниження прибутковості галузі вівчарства [16].

Про позитивну дію протеїнової рівноваги раціону та достатньої кількості вітамінів, мікро- та макроелементів на процеси сперматогенезу повідомляють багаточисленні дослідники. Функція і механізм дії біологічно-активних речовин тісно пов'язаний з нервовою та гормональною системами організму, так як вони впливають на стан і діяльність органів, тканин, клітин живого організму і регулюють обмін речовин, ріст і розвиток, розмноження, адаптивні процеси, тощо [6].

Дефіцит біологічно-активних речовин у раціоні також перешкоджає нормальному процесу сперматогенезу, знижує статеву активність і якість сперми плідників. Об'єм еякуляту, активність, концентрація і резистентність сперміїв значно вищі у баранів, до раціону яких введені різні корми тваринного походження [1]

При відсутності соковитих та вітамінних кормів у раціонах баранів знижується їх статева активність і запліднювальна здатність сперми [12].

Основа раціону овець - це корми рослинного походження, у складі яких протеїну відносно мало. Тому проблема забезпечення тварин протеїном у степовій зоні України дуже актуальна, адже кормова база задовольняє лише на 7580 \% потреби громадського тваринництва в ньому.

Рівень годівлі баранів-плідників у період підготовки до парування та в період активного використання з метою отримання спермопродукції повинен бути однаковим і не викликати зниження рівня використання кормів та розладу травлення, що негативно впливає на статеву активність і якість секреторного матеріалу [17].

При інтенсивному використанні плідників з навантаженням 3-4 еякуляти на добу необхідно запроваджувати «Флашинг» - кормові норми збільшувати на 5-10 \%. Добру компенсаторну властивість при цьому мають концентрати, корми тваринного та рослинного походження зі значним рівнем протеїну, де домінує рівень протеїну. Одним із потенційних джерел кормового білка високої якості для овець може бути вегетативна маса рослин амаранта (Amaránthus). Над проблемою виробництва кормового білка, як побічного продукту при виготовленні кормового концентрату із зелених рослин - амаранта, працюють вчені багатьох країн [11].

Корми рослинного походження використовуються вівцями як в нативному стані так переробленому. Серед перероблених рослинних кормів великого значення при годівлі набувають висушені концентрати вегетативної зеленої маси рослин у вигляді гранул, брикетів. Заготівля кормів із використанням механічного зневоднення зеленої маси рослин, останнім часом викликає підвищений інтерес.

Молоде листя амаранту (Amaránthus) багате білком, каротином, мікро- та макроелементами, вітамінами (A, C, E, рибофлавін, фолієва кислота, рутин), а за амінокислотним складом наближається до ідеального білку, а також до листя люцерни, при цьому має більший вміст лізину та високу поживну цінність.

Висушений коагулянт клітинного соку зеленої маси рослини амарант, отриманий шляхом термообробки - це кормова добавка «Бефріто».

Основними характеристиками поживної цінності «Бефіто» $є$ : високий рівень сирого протеїну (понад 50 \%) при збалансованому складі за незамінними амінокислотами, сирої клітковини до $6 \%$, значна кількість природних антиоксидантів - каротиноїдів, аскорбінової кислоти, токоферолів; значний вміст мінеральних речовин - кальцію, фосфрору, магнію, заліза, марганцю, міді, що підвищують рівень використання поживних речовин раціону.

В даній кормовій добавці присутні пектини (7-10\%), що забезпечують зв'язування токсичних елементів та інших шкідливих речовин, які надходять з кормом.

Дослідженнями встановлено позитивний вплив даної добавки на рівень якісних показників інкубаційних яєць курокнесучок, а також доведено, що «Бесріто» $€$ засобом з висококалорійною протеїновою характеристикою і при використанні в годівлі підвищує ефрективність тваринництва $[3,13,14]$.

Вісник Сумського національного аграрного університету 
Тому вивчення ефективності впливу кормової добавки «Бефіто» в раціонах баранів породи овець придніпровська м'ясна на інтенсивність сперматогенезу та кількісні і якісні показники спермопродукції проводиться вперше і має не лише теоретичне, а й практичне значення, яке спрямоване на розробку засобів інтенсифікації племінного використання плідників та включає в себе певні елементи новизни.

Матеріали та методи досліджень. Науково-дослідний експеримент проводився в ТОВ «Вівчар Придніпров'я» Павлоградського району Дніпропетровської області.

Об'єкт дослідження клінічно-здорові барани-плідники породи - придніпровська м'ясна, яких відбирали за принципом пар-аналогів (за віком, живою масою, інтенсивністю росту, якісними показниками сперми) та сформували дві групи контрольна $(n=5)$ і дослідна $(n=5)$. Контрольна група отримувала основний раціон. Дослідна - додатково до раціону отримувала кормову добавку «Бесріто» у вигляді гранул в кількості $4 \%$ на тонну зерносуміші. Добовий раціон розраховано для баранів-плідників живою масою 100-105 кг і більше, при статевій активності 2-3 садки на добу. Підготовчий період 30 діб, обліковий - 35 діб. Сперму отримували на штучну вагіну від 5-ї до 8-ї години ранку. Вивчали об'єм, концентрацію, загальну кількість сперміїв в еякуляті та частку патологічних форм, активність.
Під час проведення експериментальних досліджень дотримувались міжнародних вимог «Європейської конвенції захисту хребетних тварин, що використовуються в експериментальних та інших наукових цілях» (Страсбург, 1986 р.), та відповідного Закону України «Про захист тварин від жорстокого поводження» № 3447-IV від 21. 06. 2006 р.

Отриманий цифровий матеріал оброблений методом варіаційної статистики із застосуванням програмного забезпечення MSEXCEL 2010.

Результати досліджень. Однією з умов успішного розвитку тваринництва є збереження та покращення племінних і продуктивних ознак тварин враховуючи їх відтворювальну здатність. Ефективним та швидким методом при цьому $€$ використання штучного осіменіння.

Інтенсивне відтворення поголів'я овець в господарствах різних форм власності обумовлюється комплексом біологічних, біотехнологічних, ветеринарних та організаційно-господарських факторів, які необхідно враховувати при його плануванні та організації.

Вивчення випливу кормової добавки «Бефіто» на відтворювальну здатність баранів-плідників проводили на підставі порівняльного аналізу статевої активності, об'єму еякуляту, активності руху та концентрації сперміїв, кількості патологічних форм. Оцінку здійснювали за загальноприйнятими в зоотехнії методиками (табл. 1).

Таблиця 1

Статева активність та якість сперми баранів-плідників, $\mathrm{n}=5$

\begin{tabular}{|l|c|c|}
\hline \multicolumn{1}{|c|}{ Показник } & \multicolumn{2}{c|}{ Групи баранів } \\
\cline { 2 - 3 } & Послідна & Контрольна \\
\hline Статева потенція, с. & $9,1 \pm 0,27$ & $10,8 \pm 0,32$ \\
\hline Об'єм еякуляту, мл. & $1,9 \pm 0,06$ & $1,7 \pm 0,04$ \\
\hline у \% до контролю & $+11,7$ & - \\
\hline Активність сперміїв, балів & $8,4 \pm 0,01$ & - \\
\hline у \% до контролю & $+3,7$ & $2,1 \pm 0,01$ \\
\hline Концентрація сперміїв, млрд. / см & $2,54 \pm 0,10$ & - \\
\hline у \% до контролю & $+13,9$ & $7,40 \pm 0,30$ \\
\hline Кількість патологічних форм, \% & $6,18 \pm 0,40$ & - \\
\hline до контролю & $-1,22$ & $3,791 \pm 0,10$ \\
\hline Загальна кількість сперміїв в еякуляті, млрд. & $4,826 \pm 0,12$ & - \\
\hline у\% до контролю & $+27,3$ & \\
\hline
\end{tabular}

Спермопродуктивність як складова процесу статевої активності плідників являє собою комплексну специфічну біологічну систему, тому не слід оцінювати ії за одним якимось показником, бажано визначати якомога більше тестів, так як ця система відзначається складністю і динамічністю. Рівень спермопродуктивності баранів-плідників визначається як видовою, породною належністю, віком, живою масою, продуктивністю тварин, так і індивідуальними особливостями їх організму та впливом на них різних паратипових факторів. Так як статева активність плідників $є$ складним нейрогуморальним процесом, то одержані нами результати, стосовно витраченого часу на отримання одного еякуляту 9,1-10,8 с. вказують на відповідність їх фізіологічного стану стосовно інтенсивності процесу сперматогенезу та рівень спермопродукції. Статева потенція у плідників дослідних груп була достатньо високою. На нашу думку рівень статевої активності не в повній мірі залежить від кормового фактора, а в більшій мірі від типу нервової діяльності.

Серед плідників, основних сільськогосподарських тварин, що утримують та використовують в аграрному виробництві, барани мають середній об'єм одного еякуляту, який знаходиться в межах від 1,5-2,2 мл. і залежить від віку та інтенсивності використання плідників.

Середній об'єм отриманого еякуляту від баранів контрольної групи в межах 1,7 мл. Цей кількісний показник у плідників дослідної групи на 11,7 \% більше, що вказує на позитивний вплив кормової добавки «Бефіто» на інтенсивність сперматогенезу в організмі піддослідних тварин.

Активність руху сперміїв це важливий показник початкової оцінки якості отриманої спермопродукції, що оцінюється за 10-бальною шкалою. Еякулят баранів-плідників в якому активний поступальний рух сперміїв нижче 7,5 балів або взагалі відсутній, непридатний для використання при штучному осіменінні.

Отримані результати вказують на помітний позитивний вплив додатково введеного до раціону протеїнового концентрату на рівень активного реотаксиса у гамет. Активність руху сперміїв у піддослідних баранів-плідників знаходиться в межах 8,1-8,4 балів, тобто 81,0 - 84,0 \% мали прямолінійний поступальний рух. Реотаксис сперміїв еякуляту баранів-плідників дослідної групи на 3,7 \% вище порівняно з контролем.

Концентрація спермальних клітин у 1 мл еякуляту, а 
також загальна їх кількість в ньому, характеризують рівень функціональної активності основних статевих залоз у плідників - сім'яників. Цей показник як орієнтир при підготовці еякуляту до подальшого використання та формуванні спермодоз для штучного осіменіння.

Від концентрації спермальних клітин у еякуляті залежить їх життєздатність. Дослідженнями встановлена пряма залежність, де чим вище концентрація спермальних клітин в еякуляті, тим більше їх життєздатність в порівняно з малою [15].

Що доданого показника в еякуляті піддослідних плідників, то вона у тварин дослідної групи була вищою над контролем на 0,31 млрд./мл., що становить 13,9 \%. Враховуючи середній об'єм отриманого еякуляту, відповідна перевага плідників дослідної групи за загальною кількістю сперміїв в ньому становить 27,3 \% по відношенню до контролю.

Тенденцію до підвищення рівня кількісних показників сперми дослідної групи можна пояснити додатковим введенням до раціону протеїнового концентрату рослинного походження, що дає можливість інтенсифікувати процеси сперматогенезу в період активного використання плідників.

Дослідженнями встановлено, що додаткове введення кормової добавки впродовж підготовчих та дослідного періодів стимулює процеси сперматогенезу, не викликаючи тератогенність статевих клітин. Кількість патологічних форм сперміїв у плідників всіх груп в межах фрізіологічної норми. У контролі їх було 7,40 \% проти 6,8 \% у дослідній при максимально допустимій нормі $14 \%$.

Ефективність використання біологічних і технологічних факторів в процесі виробництва і відтворення пов'язано з організацією виробничих процесів, тому вартість відтворення стада і приріст продукції (генотипової і френотипової) $€$ контрольованими показниками. 3 врахуванням отриманих результатів, стосовно впливу «Бефріто» на статеву активність і якість спермопродукції слід зазначити, що запровадження такої моделі використання органічної добавки дозволить підвищити рівень племінної роботи за рахунок штучного осіме- ніння і забезпечить інтенсифікацію відтворення у м'ясному вівчарстві.

Технологією штучного осіменіння овець передбачається використання нативної (нерозбавленої та розбавленої) або кріоконсервованої сперми. Об'єм спермодози при використанні нативної нерозбавленої сперми становить - 0,050,07 мл., а розбавленої - 0,12-0,15 мл., з концентрацією активних спермальних клітин не нижче 80 млн. [7].

Нами проводилось штучне осіменіння вівцематок нативною нерозбавленою спермою. Об'єм спермодози 0,12 мл. при середній концентрації спермоклітин 250-300 млн.

Враховуючи середній об'єм еякуляту дослідної і контрольної груп та об'єм спермодози для штучного осіменіння, від плідників, що споживали кормову добавку «Бефріто» ми можемо отримати 15,8 спермодоз в розрахунку на 1 голову проти14,2 в контролі, що на 11,3\% більше.

Таким чином використання кормової добавки «Бефіто» в раціонах баранів-плідників породи - придніпровська м'ясна в парувальний період, дало можливість покращити показники статевої активності та рівня спермопродуктивності.

Висновки. 1. Додаткове ведення до раціону плідників кормової добавки органічного походження «Бефіто» мало позитивний вплив на інтенсивність сперматогенезу в організмі піддослідних тварин, про що свідчать кількісні і якісні показники сперми.

2. Середні показники якості сперми баранів-плідників вірогідно (за об'ємом на 11,7 \%, концентрацією на 13,9 \%, активністю на 3,7 \%, загальною кількістю сперміїв в еякуляті на 27,3 \%) були вищими за рівнем даних показників у контрольної групи, при цьому поступались на 1,2 \% за кількістю патогенних форм.

3. За рахунок додаткового введення в раціон протеїну рослинного походження підвищився об'єм еякуляту та загальна кількість сперміїв, що дало можливість отримати на 11,3 \% більше спермодоз для використання їх при штучному осіменінні вівцематок.

\section{Список використаної літератури:}

1. Айбазов М. М., Абонеев В. В. Биотехнология воспроизводства овец и коз. Ставрополь, 2004. 324 с.

2. Бурова Г. А. Исскуственное осеменение овец. М. : РГАУ-МСХА, 2010. 59 с.

3. Гречанюк А. М., Чумак В. О. Кормова добавка з амаранту «Бефіто» - засіб підвищення ефективності тваринництва. Птахівництво. 2003. Вип. 6, С. 240-241.

4. Давиденко В. М., Яблонський В. А. Теорія і практика біотехнології відтворення племінних баранів. Миколаїв, 2004. $345 \mathrm{c}$.

5. Ерохин А. И., Карасев Е. А., Ерохин С. А. Интенсификация воспроизводства овец. М., 2012. 255 с.

6. Калашников А. П. Нормы и рационы кормления сельскохозяйственных животных. Москва, 2003. 456 с.

7. Кравченко Н. И. Актуальные вопросы реализации генетического потенциала многоплодия мериносових овец. Овцы, козы, шерстяное дело. 2011. Вып. 4, С. 18-19.

8. Павлюк М. В. Технологія відтворення сільськогосподарських тварин. Київ: НМЦ «Агроосвіта», 2017. 140 с.

9. Похил В. І., Задорожня О. М. Ефективність використання баранів-плідників породи олібс в степовій зоні України. Тваринництво України. 2005. Вип. 8, С. 17-19.

10. Похил В. І., Миколайчук Л. П. М'ясна продуктивність молодняку овець різного походження. Theoretical and Applied Veterinary Medicine. 2020. Вип. 8(1), С. 26-30. DOI: https://doi.org/10.32819/2020.81005

11. Стапай П. В., Макар І. А., Гавриляк В. В. Фізіолого-біохімічні основи живлення овець. Львів: ДП «Лео-Бланк», 2007. $98 \mathrm{c}$.

12. Харута Г. Г. Відтворення с.-г. тварин: навчальний посібник. Біла Церква: БНАУ, 2011. 328 с

13. Чумак В. О. Вплив кормової добавки «Бефріто» на продуктивність та деякі показники якості інкубаційного яйця курокнесучок. Зб .наук. пр. ВДАУ. Вип. 22. (Ч.2). Вінниця, 2005. С. 122-126. 
14. Чумак В. О. Вплив кормової добавки «Бефіто» на продуктивність та деякі показники крові відлучених поросят. Вісник ДДАУ. 2005. Вип. 2, С. 61-63.

15. Яблонський В. А. Біотехнологія відтворення тварин. К.: Арістей, 2005. 296 с.

16. Cogni Y., Poulin N., Locatelli Y., Mermillod P. State of art production, conservation and transfer of in vitro produced embryos in small ruminants. Reprod. Fertil. Dev. 2004, v. 16, pp. 437-445.

17. Gonzalez-Bulnes F., Baird D.T., Campbell B.K. Multiple factors affecting the efficiency of multiple ovulation and embryo transfer in sheep and goats. Reprod. Fertil. Dev., 2004, v. 16, pp. 421-435.

18. Pokhyl V. I., Mykolaichuk L. P.Methodological fundamentals of the creation of specialized meat branch in sheep breeding of the Dnipro region. Scientific developments of Ukraine and EU in the area of natural sciences: Collective monograph. Riga: Izdevniecība «Baltija Publishing», 2020. pp. 581-597. DOI: https://doi.org/10.30525/978-9934-588-73-0/2.10

\section{References:}

1. Ajbazov, M. M. and Aboneev, V. V., 2004. Biotehnologija vosproizvodstva ovec i koz [Biotechnology of sheep and goat reproduction]. Stavropol', pp. 324.

2. Burova G. A., 2010. Isskustvennoe osemenenie ovec. [Artificial insemination of sheep] M. : RGAU-MSHA, pp. 59.

3. Grechanjuk, A. M. and Chumak, V. O., 2003. Kormova dobavka z amarantu «Befito» - zasib pidvyshhennja efektyvnosti tvarynnyctva [Befito amaranth feed additive is a means of increasing the efficiency of animal husbandry]. Ptahivnyctvo, issue, 6 , pp. $240-241$.

4. Davydenko, V. M. and Jablons'kyj, V. A., 2004. Teorija i praktyka biotehnologii' vidtvorennja pleminnyh baraniv [Theory and practice of biotechnology of reproduction of breeding rams]. Mykolai'v, pp. 345.

5. Erohin, A. I. and Karasev, E. A., 2012. Intensifikacija vosproizvodstva ovec. [Intensification of Sheep Reproduction]. M, 255.

6. Kalashnikov, A. P., 2003. Normy i raciony kormlenija sel'skohozjajstvennyh zhivotnyh. [Rates and rations for feeding farm animals]. Moskva, 456.

7. Kravchenko N. I., 2011. Aktual'nye voprosy realizacii geneticheskogo potenciala mnogoplodija merinosovih ovec [Topical issues of the implementation of the genetic potential of multiple pregnancies in merino sheep]. Ovcy, kozy, sherstjanoe delo. [Sheep, Goats, Woolen Work]. Issue. 4, pp. 18-19.

8. Pavljuk, M. V., 2017. Tehnologija vidtvorennja sil's'kogospodars'kyh tvaryn [Technology of reproduction of farm animals]. Kyiv: NMC «Agroosvita», 140.

9. Pokhyl, V. I. and Zadorozhnja, O. M., 2005. Efektyvnist' vykorystannja baraniv-plidnykiv porody olibs v stepovij zoni Ukrai'ny [Efficiency of use of breeding sheep of the Olibs breed in the steppe zone of Ukraine]. Tvarynnyctvo Ukrai'ny, issue. 8, pp. 17-19.

10. Pokhyl, V. I. and Mykolajchuk, L. P., 2020. М'ясна продуктивність молодняку овець різного походження [Меat productivity of young sheep animals of different origin]. Theoretical and Applied Veterinary Medicine, issue. 8(1), pp. 26-30. DOI: https://doi.org/10.32819/2020.81005

11. Stapaj, P. V., Makar, I. A. and Gavryljak, V. V., 2007. Fiziologo-biohimichni osnovy zhyvlennja ovec' [Physiological and biochemical bases of sheep nutrition]. L'viv : DP «Leo-Blank», 98.

12. Haruta, G. G., 2011. Vidtvorennja s.-g. tvaryn. [Reproduction of agricultural animals]. Bila Cerkva : BNAU, 328.

13. Chumak, V. O., 2005. Vplyv kormovoi' dobavky «Befito» na produktyvnist' ta dejaki pokaznyky jakosti inkubacijnogo jajcja kurok-nesuchok [Influence of Befito feed additive on productivity and some quality indicators of hatching eggs of laying hens]. $\mathrm{Zb}$. nauk. pr. VDAU. Issue. 22. (2). Vinnycja, pp. 122-126.

14. Chumak V. O., 2005. Vplyv kormovoi' dobavky «Befito» na produktyvnist' ta dejaki pokaznyky krovi vidluchenyh porosjat [Influence of Befito feed additive on productivity and some blood parameters of weaned piglets]. Visnyk DDAU, issue. 2, pp. 61-63.

15. Jablons'kyj, V. A., 2005. Biotehnologija vidtvorennja tvaryn. [Biotechnology of animal reproduction]. K. : Aristej, 296.

16. Cogni, Y., Poulin, N., Locatelli, Y. and Mermillod, P., 2004. State of art production, conservation and transfer of in vitro produced embryos in small ruminants. Reprod. Fertil. Dev, issue. 16, pp. 437-445.

17. Gonzalez-Bulnes, F., Baird, D. T. and Campbell, B. K., 2004. Multiple factors affecting the efficiency of multiple ovulation and embryo transfer in sheep and goats. Reprod. Fertil. Dev, issue. 16, pp. 421-435.

18. Pokhyl, V. I. and Mykolaichuk, L. P., 2020. Methodological fundamentals of the creation of specialized meat branch in sheep breeding of the Dnipro region Scientific developments of Ukraine and EU in the area of natural sciences: Collective monograph. Riga: Izdevniecība «Baltija Publishing», pp. 581-597. DOI https://doi.org/10.30525/978-9934-588-73-0/2.10

Pokhyl Volodymyr Ivanovych, PhD of Agricultural Sciences, Associate Professor

Pokhyl Elena Mykolaevna, PhD of Agricultural Sciences, Associate Professor

Mykolaychuk Lyudmyla Petrovna, assistant

Pavlenko Roman Anatoliyovych, magister

Dnipro State Agrarian and Economic University

\section{Influence of a feed additive of organic origin on the sexual activity of rams}

Organization of balanced feeding that meets the needs of producers in nutrients and vitamins, with a certain physiological state and level of performance, is one of the main factors in the process of ensuring complete spermatogenesis and quality indicators of sperm. Due to the fact that for many reasons protein deficiency is observed in feed rations (prices, feed quality, competition), the provision of a sufficient amount of protein in it is one of the main conditions for obtaining high-quality sperm production. The results of studies of the influence of the feed additive "Befito" of organic origin on the reproductive capacity and quality of sperm production of 
sheep of the Pridneprovskaya meat breed are presented. It was found that the use of the feed additive "Befito" in the diets provides an improvement in the process of spermatogenesis and affects the increase in quantitative and improvement in the quality indicators of sperm production. The level of time for receiving one ejaculate from manufacturers is 9.1-10.8 s, which indicates their high sexual activity and potency. The volume of the obtained ejaculate from the rams of the research group by $11.7 \%$, the activity of spermatozoa by $3.7 \%$, the concentration of spermatozoa in the ejaculate is $13.9 \%$ higher than that of the control analogues. The advantage of the producers of the research group is observed in the total number of sperm in the ejaculate and is $+27.3 \%$. At the same time, teratogenicity of germ cells is not observed. The level of pathological sperm forms in the ejaculate is within the physiological norm (< 14 $\%)$.Considering the average volume of ejaculate from the rams of the research group, 15.8 sperm doses were received per head versus 14.2 in the control, which is $11.3 \%$ more. The results obtained allow us to consider it expedient to use the feed additive "Befito" to improve the process of spermatogenesis and the quality of sperm and recommend it as the most effective.

Key words: breeding rams, reproductive capacity, feed additive, amaranth, ejaculate volume, sperm production, rheotaxis, sperm concentration.

Дата надходження до редакції: 29. 10.2020 р. 